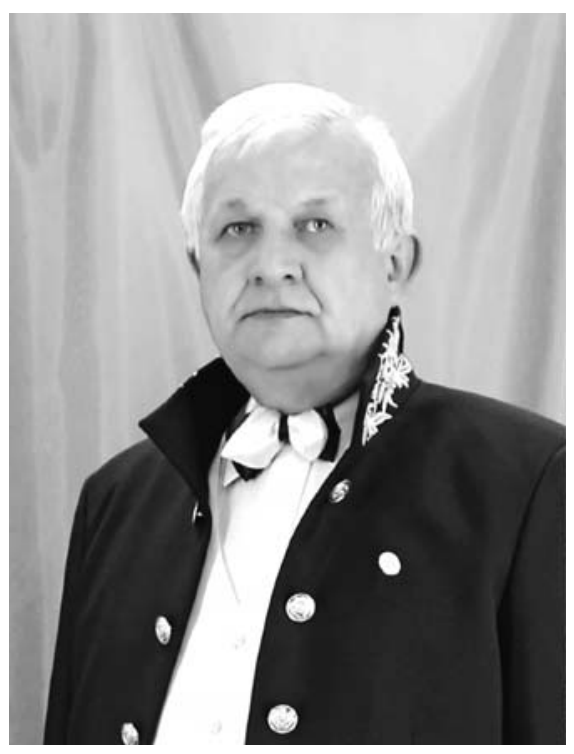

(17.02.1947 - 28.07.2014)

\title{
IN MEMORY OF CORRESPONDING MEMBER OF ACADEMY OF SCIENCES OF MOLDOVA PROFESSOR MIHAIL REVENCO
}

Mr. Mihail Revenco, corresponding member of the Academy of Sciences of Moldova, Professor, Dr. habilitate in chemistry, was born on $17^{\text {th }}$ February 1947 in the village Badiceni, distinct Soroca. After graduating the secondary school in his native village in 1964, he was registered at the Faculty of Chemistry of the Moldova State University, in 1969. During the years 1969-1973 he followed the PhD studies at the Department of Inorganic Chemistry, Faculty of Chemistry of the Moldova State University. In 1973 he obtained the Ph.D. degree and the degree of Doctor Habilitate in Chemistry in 1991. Since 1992 he held the title of university professor.

The didactic activity began at the State Agrarian University of Moldova (1972-1987), then Mihail Revenco activated at the Hydrotechnical Institute from Blida, Algeria (1978-1982). Several years he worked at the Moldova State University, as head of the Department of Organic and Analytical Chemistry (1988-2006), Dean of the Faculty of Chemistry and Chemical Technology (2007-2008). Since 2008 he held the position of vice-rector for scientific activity. In 2012 he was elected the corresponding member of the Academy of Sciences of Moldova.

The chemist Mihail Revenco has worked many years also at the Institute of Chemistry of the Academy of Sciences of Moldova. Thus, in the period 1997-2006 he led the scientific activity of the Laboratory of Analytical Chemistry and during of 2006-2007 - of Laboratory of Coordination Chemistry.

Specialist in coordination and analytical chemistry, he was argued as a skillful organizer of the university process, the erudite professor, appreciated by colleagues and students, the talented scholar of international value, manager of scientific projects carried out with the participation of teams from Europe and the United States in programs NATO, INTAS, CRDF, SCOPES. His scientific interests were focused towards the assembly reactions and its application for analytical or medico-biological purposes. Contributed to the reform of secondary education, he was the author of the school curricula and textbook related to the bases of chemical analysis.

Professor Mihail Revenco, together with the late Academician Nicolae Garbalau, in the early 70's of the last century, discovered a new method of synthesis in coordination chemistry - the assembly method of ligands based on the thiosemicarbazides in the presence of metal ions. In this way, the template method of synthesis of this class of coordination compounds have been arose, which, at present, has been recognized and used worldwide and became the basis of the assembly method of the supramolecules.

Scientific research of chemist Mihail Revenco was focused on the application of the assembly reactions for analytical purpose, valorization of the coordination compounds in the sensitive methods of analysis. On the basis of these reactions, it has been proposed the original structures for membranes of potentiometric sensors, the convenient devices for the analysis and analytical control of the content of ionic species. The scientific basis of analytical coordination chemistry with polyfunctional derivatives was developed, the field which was promoted with passion together with his students. 
The achievements of fundamental and applied scientific research performed by the chemist Mihail Revenco were the basis for the foundation of the scientific school in the field of coordination and analytical chemistry which was further recognized abroad. The rich scientific activity of Professor Mihail Revenco was eloquently described by the high number of scientific papers that exceeded 400, published in national and international journals with impact factor. He is also the author of 4 monographs, 8 patents, and 12 didactic materials. The achievements of the scientific school founded by corresponding member Mihail Revenco has been highly appreciated by various international scientific centers.

Scientific work and practical results of Professor Mihail Revenco were deservedly appreciated by superior bodies, being awarded the National Award in Science and Technology (1995), Order of "Emeritus" of the Republic of Moldova (1996), “Dimitrie Cantemir” Medal (2006), "Paisie Velcikovsky” Medal (Poland 2011), the Memorial Award "Yurii Simonov” (2012). In 2012, for outstanding results, through Presidential Decree, Professor Mihail Revenco was awarded the Order "Labour Glory”.

The famous French art historian and essayist Jacques Élie Faure said following "A man when he is gone, nothing is left of him if he took care to leave, at least, a trace on stones road”. This message is for us an urge to leave traces and good things throughout our life on Earth, as always took care to do our friend, scientist, professor and Personality Mihail Revenco.

Academician Gheorghe Duca, President of the Academy of Sciences of Moldova

Corresponding member Tudor Lupascu,

Director of the Institute of Chemistry of A.S.M. 